\title{
Uwagi na tle wyroku Wojewódzkiego Sądu Administracyjnego w Poznaniu z dnia 4 listopada 2016 r. (sygn. IV SA/Po 495/16)
}

Wyrok Wojewódzkiego Sądu Administracyjnego (WSA) w Poznaniu zasługuje na uwagę, ze względu na poruszane w nim kwestie dotyczące ustalenia momentu zakończenia postępowania administracyjnego w związku z żądaniem organizacji społecznej dopuszczenia jej do udziału w postępowaniu.

Wyrokiem z 4 listopada 2016 r. (sygn. IV SA/Po 495/16) WSA w Poznaniu uchylił postanowienie Samorządowego Kolegium Odwoławczego (SKO) w Poznaniu, które zostało wydane wskutek zażalenia złożonego przez organizację społeczną. $W$ rozpatrywanej przez sąd sprawie organ I instancji (Prezydent Miasta Poznania) odmówił dopuszczenia organizacji społecznej do udziału w postępowaniu, a następnie SKO w Poznaniu utrzymało to postanowienie w mocy. Organy obu instancji uzasadniły swoje stanowisko brakiem wykazania przez organizację zasadności ochrony interesu społecznego w przedmiotowym postępowaniu. Organizacja społeczna wniosła skargę do WSA na rozstrzygnięcie organu II instancji. Sąd uchylił zaskarżone postanowienie i umorzył postępowanie odwoławcze, akcentując znaczenie momentu zakończenia postępowania administracyjnego dla oceny legalności tego postanowienia. 
W uzasadnieniu głosowanego wyroku WSA wskazał, że w dacie wydania postanowienia przez SKO, organ I instancji decyzją odmówił inwestorowi ustalenia warunków zabudowy. Decyzja ta nie została zaskarżona i stała się ostateczna, na kilka miesięcy przed wydaniem przez SKO zaskarżonego postanowienia. Dokonując oceny legalności zaskarżonego aktu, sąd podniósł, że istotne znaczenie dla sprawy miał moment zakończenia postępowania w sprawie ustalenia warunków zabudowy. WSA wskazał, że instytucja dopuszczenia organizacji społecznej do udziału w postępowaniu nie funkcjonuje samodzielnie, abstrakcyjnie, w oderwaniu od konkretnej sprawy. Jednocześnie, powołując się na judykaturę, sąd stwierdził, że instytucja ta ma pełne odniesienie do sytuacji, w której wniosek z art. $31 \S 1$ pkt 2 Kodeksu postępowania administracyjnego ${ }^{1}$ jest złożony $\mathrm{w}$ czasie, gdy nie toczy się postępowanie administracyjne $\mathrm{w}$ danej sprawie, dlatego że nie zostało ono wszczęte bądź dlatego, że zostało ostatecznie zakończone. W dalszej kolejności sąd stwierdził, że w przypadku złożenia przez organizację społeczną wniosku o dopuszczenie do udziału w postępowaniu na podstawie art. $31 \S 1$ pkt 2 k.p.a., uprawnienie organizacji do dopuszczenia jej do udziału w postępowaniu na prawach strony (art. 31 \& 3 k.p.a.) nie wygasa wskutek wydania decyzji kończącej to postępowanie nawet wówczas, gdy decyzja ta nabyła cechę formalnej ostateczności wobec niewniesienia odwołania. Powołując się na stanowisko judykatury, sąd wskazał, że wniosek ten nadal podlega merytorycznemu rozpatrzeniu, a w razie pozytywnego jego załatwienia decyzja ta traci powyższą cechę i podlega doręczeniu tej organizacji stosownie do art. 109 § 1 w zw. z art. 31 \& 3 k.p.a. WSA, powołując się na wcześniejsze poglądy judykatury, podkreślił też, że jeśli wniosek organizacji wpływa w toku postępowania, to nawet jeśli po negatywnym jego rozpoznaniu zostanie złożony środek zaskarżenia (zażalenie), organ nie może oczekiwać na moment, gdy decyzja wydana w postępowaniu głównym stanie się ostateczna, lecz winien rozpoznać zażalenie ${ }^{2}$.

Na kanwie uzasadnienia wyroku WSA nasuwają się znaczące wnioski. Po pierwsze, jak w glosowanym wyroku słusznie przyjęto, każdy rozpatrywany przypadek wymaga rozpatrzenia wszystkich okoliczności sprawy. Po drugie, istotne znaczenie dla załatwienia wniosku organizacji

${ }^{1}$ Ustawa z dnia 14 VI 1960 r. Kodeks postępowania administracyjnego (tekst jedn. Dz.U. 2016, poz. 23 ze zm.), dalej „k.p.a.”.

${ }^{2}$ Wyrok Naczelnego Sądu Administracyjnego (NSA) z 25 X 2013 r., sygn. II OSK 1217/12, www.nsa.gov.pl (dostęp: 12 I 2017). 
o dopuszczenie do udziału w postępowaniu ma ustalenie, do jakiego momentu można taki wniosek złożyć, co może rodzić w praktyce wiele wątpliwości.

Przepis art. $31 \S 1$ pkt 2 k.p.a. stanowi, że organizacja społeczna może w sprawie dotyczącej innej osoby występować z żądaniem dopuszczenia jej do udziału w postępowaniu, jeżeli jest to uzasadnione celami statutowymi tej organizacji i gdy przemawia za tym interes społeczny. W naturalny sposób rodzi się pytanie o to, w jakiej sytuacji organ administracji publicznej może uznać, że uprawnienie organizacji społecznej do wystąpienia $z$ takim żądaniem wygasło. Który moment jest momentem ostatecznym dla merytorycznego rozpatrzenia wniosku? Bezspornie, przepis art. $31 \S 1$ pkt 2 k.p.a. nie określa momentu, do którego należy wniosek złożyć. Ustawodawca wskazuje wprost, że „żądanie” dotyczy "sprawy innej osoby" i, że jest to „żądanie” o dopuszczenie do „udziału w postępowaniu". W literaturze podaje się, iż organizacja społeczna może żądać dopuszczenia jej do udziału w już toczącym się postępowaniu, a zatem w postępowaniu zwykłym przed organami I i II instancji, a także w tzw. postępowaniach nadzwyczajnych od daty wszczęcia postępowania do daty wydania decyzji w danej instancji ${ }^{3}$. Z przepisów nie wynika też, czy postępowanie, o którym mowa w przepisach art. 31 $\S 1$ i 2 k.p.a., należy rozumieć szeroko, jako postępowanie w sprawie dotyczącej innej osoby, które obejmuje postępowanie w trybie zwykłym i nadzwyczajnym, czy też wąsko, jako postępowanie toczące się przed organem danej instancji, od daty jego wszczęcia do daty wydania decyzji nieostatecznej ${ }^{4}$. Skoro jednak ustawodawca wyraźnie odróżnia żądanie wszczęcia postępowania od żądania dopuszczenia do udziału w postępowaniu, to oznacza to, że "dopuszczenie do udziału” dotyczy postępowania, które jest w toku. Wobec tego zasadnicze znaczenie ma zdefiniowanie pojęcia "toku postępowania” administracyjnego, w trakcie którego organizacja społeczna ma prawo domagać się dopuszczenia do udziału w postępowaniu. Jakkolwiek ogólnie przez tok postępowania rozumie się pewien usystematyzowany ciąg działań organów administracji publicznej, podjęty w celu rozpatrzenia i rozstrzygnięcia sprawy ${ }^{5}$, to w doktrynie i orzecznictwie nie ma zgodności co do szczegółowego

${ }^{3}$ A. Wróbel, Komentarz do art. 31 k.p.a., w: M. Jaśkowska, A. Wróbel, Kodeks postępowania administracyjnego, Zakamycze 2005, s. 310.

${ }^{4}$ Ibidem.

${ }^{5}$ Z. Kmieciak, Instancja i tryb postępowania administracyjnego a prawo strony do żadania jego umorzenia, "Samorząd Terytorialny” 2008, nr 5, s. 61-68. 
pojmowania tego terminu. $W$ tym zakresie pojawiają się dwa główne nurty poglądów. Pierwszy - zgodnie z którym pojęcie toku postępowania obejmuje nie tylko czynności procesowe podejmowane od momentu wszczęcia postępowania do chwili uzyskania przez decyzję cechy ostatecznej, ale także czynności przedprocesowe podejmowane w celu uruchomienia toku oraz wyjątkowo czynności wykonywane po jego ustaniu, gdy istnieją dla nich podstawy prawne ${ }^{6}$. Zwolennicy tego poglądu przyjmuja, że wniesienie odwołania nie następuje poza tokiem postępowania administracyjnego, bowiem postępowanie odwoławcze jest dalszym ciągiem postępowania pierwszoinstancyjnego ${ }^{7}$. Przyjmuje się wówczas, że postępowanie pierwszoinstancyjne kończy się z chwilą uprawomocnienia się decyzji ${ }^{8}$. Według drugiego poglądu tok postępowania uruchamianego na żądanie strony rozpoczyna się z chwilą wpłynięcia podania (wniosku o przyznanie uprawnienia lub o wydanie decyzji w inny sposób poszerzającej sferę uprawnień strony, odwołania, wniosku o wznowienie postępowania, wniosku o stwierdzenie nieważności decyzji, wniosku o wzruszenie w inny sposób decyzji ostatecznej) do organu właściwego do jego rozpatrzenia, kończy zaś $\mathrm{z}$ chwilą wydania przez organ decyzji w danej instancji ${ }^{9}$.

Jeszcze inaczej pojęcie toku postępowania administracyjnego wydaje się rozumieć WSA we Wrocławiu, który stanął na stanowisku, że postępowanie administracyjne toczy się od chwili jego wszczęcia do momentu wyczerpania wszystkich środków zaskarżenia, w tym nadzwyczajnych, jak też przysługujących przed sądami administracyjnymi. Jednym z etapów tego postępowania jest postępowanie odwoławcze ${ }^{10}$.

Podobnie jak w przypadku terminu "tok postępowania”, tak i w odniesieniu do pojęcia "zakończenie postępowania” brak jest jednoznacznych ustaleń doktryny i orzecznictwa. Wobec wielości poglądów (i judykatury, i doktryny) co do tego, w którym momencie kończy się postępowanie administracyjne, odpowiedź na to pytanie wcale nie wydaje się łatwa. Poczynienie ustaleń w tym zakresie jest o tyle istotne,

${ }^{6}$ W szczególności: wyrok NSA z 21 IV 2016 r., sygn. I OSK 2245/14; G. Łaszczyca, Postanowienie administracyjne w ogólnym postępowaniu administracyjnym, Warszawa 2012.

${ }^{7}$ W. Czerwiński, Niektóre aspekty udziału prokuratora w postępowaniu administracyjnym, http://www.zielona-gora.po.gov.pl/magazyn/upload/lektury_elektroniczne/czerwin ski-dla-zielonej-gory.doc (dostęp: 8 I 2017).

${ }^{8}$ Ibidem.

${ }^{9}$ Z. Kmieciak, op. cit., s. 63.

${ }^{10}$ Wyrok WSA we Wrocławiu z 2 II 2007 r., sygn. III SA/Wr 494/08, www.nsa.gov. pl (dostęp: 12 I 2017). 
że w demokratycznym państwie prawnym jednostka zwracająca się z konkretnym żądaniem do organu administracji publicznej powinna nie mieć wątpliwości, iż każdy orzekający w jej sprawie organ administracji publicznej, kierując się tymi samymi przesłankami, na gruncie tego samego stanu faktycznego i prawnego wydałby rozstrzygnięcie o takiej samej treści. Upraszczając zatem, negatywnie należy postrzegać sytuację, w której podmioty występujące $z$ takim samym żądaniem, w tożsamym stanie faktycznym i prawnym zostaną różnie potraktowane przez organy administracji publicznej. Tymczasem prawdopodobieństwo takich zdarzeń jest tym większe, im większa jest różnorodność poglądów dotyczących słuszności możliwych do zastosowania rozwiązań danego problemu.

Poszukując zatem odpowiedzi na pytanie o jednoznaczne rozwikłanie zarysowanego problemu, analizie poddać należy koncepcje odnoszące się do momentu zakończenia postępowania administracyjnego. W tym zakresie na osi czasu można wskazać trzy daty: (1) datę wydania decyzji, (2) datę doręczenia lub ogłoszenia decyzji, (3) datę, z którą decyzja stała się ostateczna.

Najwcześniejszym momentem, z którym można wiązać zakończenie postępowania administracyjnego, jest chwila wydania decyzji. Sąd Najwyższy w wyroku z 2 października 2002 r. ${ }^{11}$ stanął na stanowisku, że "wydanie decyzji jest czynnością procesową organu administracji publicznej polegającą na podpisaniu decyzji zawierającej wymagane prawem elementy". Pogląd ten znajduje pełne poparcie w orzecznictwie sądowoadministracyjnym. Naczelny Sąd Administracyjny stwierdza bowiem, że "za wydanie decyzji administracyjnej, a tym samym załatwienie sprawy", można uznać datę, w której akt administracyjny zaopatrzony został we wszystkie niezbędne elementy tej formy działania administracji publicznej ${ }^{12}$. Podkreślić przy tym należy, że NSA w wielu swoich orzeczeniach wyraźnie odróżnia moment wydania (sporządzenia) decyzji od momentu jej doręczenia ${ }^{13}$. Zdaniem NSA sprawa jest załatwiona w chwili wydania przez organ aktu kończącego postępowanie, decyzja administracyjna rozpoczyna bowiem swój byt prawny z chwilą

${ }^{11}$ Wyrok Sądu Najwyższego (SN) z 12 IV 2012 r., sygn. III RN 149/01, OSNP 2003, nr 16, poz. 371.

${ }_{12}$ Wyrok NSA z 25 IV 2006 r., sygn. II OSK 714/05, ONSAiWSA 2006, nr 5, poz. 132 (dostęp: 12 I 2017).

${ }^{13}$ Wyroki NSA: z 25 IV 2006 r., sygn. II OSK 714/05; z 28 II 2008 r., I OSK 175/07; z 5 III 2009 r., sygn. I OSK 453/08, www.nsa.gov.pl (dostęp: 26 II 2017). 
jej sporządzenia, a doręczenie ma na celu jedynie zakomunikowanie stronie zawartego w niej rozstrzygnięcia, które następuje w chwili złożenia na decyzji podpisu osoby uprawnionej. NSA nie podziela poglądu, że w okresie pomiędzy datą sporządzenia decyzji a momentem jej zakomunikowania stronie sprawa nie została zakończona ${ }^{14}$. W orzecznictwie zauważa się, że fakt, iż decyzja administracyjna wywiera skutki prawne dopiero $z$ chwilą doręczenia stronie, nie oznacza, by wcześniej nie istniała, gdyż z chwilą podpisania decyzji mamy do czynienia z wydaniem decyzji w sensie procesowym w tym znaczeniu, że istnieje decyzja administracyjna, a dzień jej wydania jest miarodajny dla oceny podstawy prawnej i podstawy faktycznej tej decyzji ${ }^{15}$.

Pogląd, zgodnie z którym zakończenie postępowania administracyjnego należy utożsamiać $z$ datą sporządzenia decyzji administracyjnej, może jednak budzić zastrzeżenia. NSA w wyroku z 25 kwietnia $2006 \mathrm{r}$. zauważa, że na gruncie art. 72 Rozporządzenia Prezydenta Rzeczypospolitej Polskiej z dnia 22 marca 1928 r. o postępowaniu administracyjnym ${ }^{16}$ rozróżniono „moment, z którym decyzję można uznać za powstałą", i moment, z którym "decyzję faktycznie istniejącą można uznać za wydaną". Podkreślano wówczas, że do chwili doręczenia (ogłoszenia) każda decyzja, nawet podpisana, musi być uważana za projekt decyzji, albowiem może być jeszcze przez władzę cofnięta lub zmieniona ${ }^{17}$. NSA w wyroku z 25 kwietnia 2006 r. zastrzegł jednak, że pogląd ten wypowiedziany został na gruncie r.p.a., w którym nie było odpowiednika dzisiejszego art. 110 k.p.a., wprowadzonego do ogólnego postępowania administracyjnego w k.p.a. w 1960 r. Przypomnijmy, że przepis art. 110 k.p.a. stanowi, iż organ administracji publicznej, który wydał decyzję, jest nią związany od chwili jej doręczenia lub ogłoszenia, o ile Kodeks nie stanowi inaczej. Bezspornie zatem ustawodawca przyjmuje, że związanie organu wydaną decyzją nie następuje $z$ chwilą jej wydania, ale $z$ chwila jej doręczenia (ogłoszenia). Organ administracji publicznej załatwia sprawę przez wydanie decyzji (art. $104 \S 1$ k.p.a.) i - jak wskazuje treść art. $104 \S 2$ k.p.a. - to decyzje kończa postępowanie $\mathrm{w}$ danej instancji. $Z$ drugiej jednak strony należy podzielić pogląd, zgodnie z którym wskazanie przez ustawodawcę,

${ }^{14}$ Wyrok NSA z 27 III 2012 r., sygn. I OSK 600/12, www.nsa.gov.pl (dostęp 2 II 2017).

15 Wyroki NSA: z 3 III 2008 r., sygn. I OSK 294/07, LEX nr 505396; z 27 VII 2010 r., sygn. II OSK 1757/09, www.nsa.gov.pl (dostęp: 2 II 2017).

${ }^{16}$ Dz.U. RP Nr 36, poz. 341, dalej „r.p.a.”.

17 J. Pokrzywnicki, Postępowanie administracyjne, Warszawa 1948, s. 186. 
w art. $107 \S 1$ k.p.a., daty wydania decyzji jako niezbędnego elementu jej treści ma przeciwdziałać sytuacji, w której za datę wydania decyzji należałoby uznać datę doręczenia jej stronie lub stronom ${ }^{18}$. Słabością stanowiska wiążącego zakończenie postępowania administracyjnego z momentem sporządzenia decyzji jest brak instrumentu kontroli nad tym procesem. Wnioskująca o dopuszczenie do udziału w postępowaniu administracyjnym organizacja społeczna nie jest w stanie $w$ żaden sposób ustalić, z jaką datą decyzja rzeczywiście została sporządzona. Ten brak instrumentu kontroli, przy założeniu, że postępowanie administracyjne kończy sporządzenie decyzji, tworzy lukę stanowiąca impuls do pewnej uznaniowości co do sposobu załatwienia wniosku organizacji społecznej o dopuszczenie do udziału w postępowaniu. Jakkolwiek literalne brzmienie przepisów k.p.a. prowadzi do wniosku o trafności argumentacji przytoczonej w wyroku NSA z 25 kwietnia 2006 r., to nie sposób przyjąć jej bezkrytycznie wobec obowiązywania zasady budowania zaufania do organów władzy publicznej (art. 8 k.p.a.) oraz zasady praworządności (art. 6 k.p.a.). Ustawodawca legitymuje organ administracji publicznej do wydania orzeczenia w sprawie dopuszczenia do udziału w toczącym się postępowaniu. To uprawnienie nie powinno być traktowane jako uprawnienie organu do uznaniowego i pozbawionego kontroli określania daty zakończenia tego postępowania. Należy też zwrócić uwagę na cel instytucji dopuszczenia organizacji społecznej do udziału w postępowaniu. Celem tym jest dopuszczenie do udziału w postępowaniu administracyjnym innych niż strony postępowania podmiotów oraz umożliwienie im reprezentacji i ochrony interesu społecznego $\mathrm{w}$ toku tego postępowania ${ }^{19}$. Podkreśla się przy tym, że uczestnictwo organizacji społecznych w postępowaniu administracyjnym należy do zbioru fundamentalnych wartości procesowych, wyznaczających ocenę danej procedury pod względem sprawiedliwości proceduralnej ${ }^{20}$. Skoro zatem intencją ustawodawcy było stworzenie instrumentu urzeczywistnienia ochrony interesu publicznego $\mathrm{w}$ toku

\footnotetext{
${ }^{18}$ Wyrok NSA z 11 V 2016 r., sygn. II GSK 2976/14, www.nsa.gov.pl (dostęp: 2 II 2017).

${ }^{19}$ Szerzej: A. Skoczylas, M. Swora, Organizacje społeczne (pozarzadowe) w postępowaniu administracyjnym i sadowoadministracyjnym, „Administracja. Teoria - Dydaktyka - Praktyka" 2006, nr 3(4), s. 13-36; A. Gronkiewicz, Organizacja społeczna w ogólnym postępowaniu administracyjnym, Warszawa 2012, s. 217 i n.; R. Suwaj, Praktyczne aspekty udziału organizacji społecznych w ogólnym postępowaniu administracyjnym, "Samorząd Terytorialny" 2010, nr 1-2, s. 39-58.

${ }^{20} \mathrm{H}$. Knysiak-Molczyk, Uprawnienia strony w postępowaniu administracyjnym, Kraków 2004, s. 11 i n.
} 
postępowania administracyjnego, to nie sposób przyjąć, że ten sam ustawodawca ocenę możliwości zastosowania tego instrumentu pozostawił swobodnej ocenie organu.

Drugim momentem, w którym upatruje się zakończenia postępowania administracyjnego $\mathrm{w}$ danej instancji, jest chwila doręczenia lub ogłoszenia decyzji. Wskazuje się na zasadę związania organu I instancji wydaną przez niego decyzją - od chwili jej doręczenia lub ogłoszenia, czyli od chwili, gdy ten akt woli organu dochodzi do wiadomości strony w sposób uregulowany przez przepisy k.p.a. ${ }^{21}$ Znawcy problemu podnosza, że związanie organu administracji wydaną przez niego decyzją ma znaczenie także dla strony, uzyskuje ona bowiem informację o definitywnym - na danym etapie postępowania - stanowisku organu w sprawie ${ }^{22}$. Podkreśla się przy tym, że organ administracji może dowolnie i wielokrotnie zmienić treść decyzji przed jej doręczeniem lub ogłoszeniem, również wówczas, gdy decyzja została podpisana. Prawny byt decyzji na zewnątrz rozpoczyna się z chwilą jej doręczenia lub ogłoszenia i dopiero od tej chwili organ, który decyzję wydał, jest nią związany ${ }^{23}$. Judykatura podkreśla, że fakt, iż organ administracji do chwili doręczenia stronie lub ogłoszenia decyzji nie jest nią związany, oznacza, że do tego momentu sporządzona decyzja pozbawiona jest jeszcze przymiotu stabilnego rozstrzygnięcia sprawy co do jej istoty. Bez tego przymiotu nie może wiązać ani organu, ani też strony. Decyzja sporządzona (a więc spełniająca wymagania formalne), ale niedoręczona, nie załatwia sprawy, ponieważ nie wiąże organu ani strony ${ }^{24}$. Zasada związania organu wydaną przez niego decyzją oznacza, że byt decyzji rozpoczyna się z chwila jej doręczenia lub ogłoszenia i to od tej chwili organ, który decyzję wydał, nie może jej zmienić ani uchylić, choćby doszedł do przekonania, że jest ona niezgodna z prawem lub też nietrafna ${ }^{25}$. W doktrynie podkreśla się, że przed doręczeniem (ogłoszeniem) decyzji organ władny jest dokonywać wszelkich zmian mimo wydania decyzji, tj. podpisania projektu zawierającego ustawowe elementy. W konsekwencji nie można wykluczyć sytuacji, kiedy przed doręczeniem albo po nieskutecznym doręczeniu (wskazanie adresu,

${ }^{21}$ Z. Janowicz, Kodeks postępowania administracyjnego, Warszawa 1996, s. 284.

22 P.M. Przybysz, Kodeks postępowania administracyjnego. Komentarz, Warszawa 2014.

${ }^{23}$ Ibidem.

${ }^{24}$ Wyrok NSA z 18 XII 2007 r., sygn. II GSK 278/07, www.nsa.gov.pl (dostęp: 2 II 2017).

25 T. Woś, Glosa do wyroku SN z dnia 3 czerwca 1993 r., III ARN 27/93, OSP 1993, z. 3, poz. 116. 
który nie istnieje) organ przystąi do wydania nowej, zmienionej decyzji, która nie będzie formalną zmianą czy uchyleniem wcześniejszej decyzji ${ }^{26} . \mathrm{W}$ świetle powyższych rozważań aktualne staje się pytanie o intencje ustawodawcy w zakresie rozróżnienia literalnego momentu wydania decyzji i momentu doręczenia tej decyzji. Jak wykazuje analiza poglądów doktryny, pod pojęciem „wydanie decyzji” należy rozumieć sporządzenie decyzji (czyli jej napisanie i podpisanie) oraz skuteczne jej doręczenie (ewentualnie ogłoszenie) ${ }^{27}$. W literaturze podkreśla się, że decyzja jako oświadczenie woli organu administracji staje się decyzją dopiero w momencie jej doręczenia, wówczas bowiem oświadczenie to skutecznie i bez wątpliwości dociera do adresata (strony) ${ }^{28}$.

Należy zauważyć, że data doręczenia aktu administracyjnego jest dokumentowana w toku postępowania administracyjnego, a dzięki temu jest możliwa do zweryfikowania. Stanowisko takie wydaje się spójne z poglądem, że z art. $109 \S 1$ w zw. z art. 110 k.p.a. nie można wywodzić, iż wydanie decyzji jest wprowadzeniem decyzji administracyjnej do obrotu prawnego. Nie zostaje bowiem uzewnętrznione oświadczenie woli organu administracji publicznej przez jego zakomunikowanie jednostce, co pozbawia je bytu prawnego w zakresie możliwości wywołania skutku prawnego ${ }^{29}$.

Wreszcie należy się zastanowić, czy jest możliwe złożenie wniosku o dopuszczenie organizacji społecznej do udziału w postępowaniu w sytuacji, kiedy decyzja staje się ostateczna ${ }^{30}$, albowiem organ odwoławczy traci wówczas możliwość merytorycznego orzekania w trybie zwykłym, w ramach procedury odwoławczej ${ }^{31}$. Podważenie decyzji ostatecznej możliwe jest wyłącznie w trybie nadzwyczajnym. Zasadności tego stanowiska upatruje się $\mathrm{w}$ fakcie, że decyzja ostateczna wydana przez organy I i II instancji jest trwała, może bowiem być wzruszona

${ }^{26}$ K. Klonowski, Komentarz do art. 110 k.p.a., w: Kodeks postępowania administracyjnego. Komentarz, pod red. H. Knysiak-Molczyk, Warszawa 2015.

27 A. Bartosiewicz, Glosa do uchwaty Naczelnego Sądu Administracyjnego z dnia 4 grudnia 2000 r., sygn. FPS 10/00, OSP 2002, nr 12, s. 154.

${ }^{28}$ W. Dawidowicz, Model postepowania w sprawie administracyjnej i obowiazywanie decyzji wydanej w sprawie, "Państwo i Prawo” 1993, z. 11-12, s. 61.

${ }^{29}$ Uchwała NSA z 15 X 2008 r., sygn. II GSP 4/08, www.nsa.gov.pl (dostęp: 2 II 2017).

${ }^{30}$ Wyrok WSA w Gliwicach z 1 III 2016 r., sygn. I SA/Gl 1209/15, www.nsa.gov.pl (dostęp: 2 II 2017).

${ }^{31}$ Wyrok WSA w Warszawie z 21 I 2016 r., sygn. IV SA/Wa 309/14, www.nsa.gov.pl (dostęp: 2 II 2017). 
w trybie postępowania administracyjnego tylko w przypadkach wyraźnie przewidzianych w k.p.a. ${ }^{32}$

Powyższe rozważania dają podstawy do ustalenia ostatecznego momentu złożenia wniosku o dopuszczenie organizacji społecznej do udziału w postępowaniu.

W pełni należy zgodzić się ze stanowiskiem, że uprawnienie $\mathrm{z}$ art. 31 $\S 1$ pkt 2 k.p.a. dotyczące dopuszczenia organizacji społecznej do udziału w postępowaniu istnieje, jeżeli postępowanie to jest $w$ toku, gdyż instytucja ta nie funkcjonuje samodzielnie, w oderwaniu od konkretnej sprawy. Ten ogólnie słuszny co do zasady pogląd musi być konfrontowany z okolicznościami faktycznymi konkretnej sprawy. Nie może być bowiem rozumiany w sposób, który w danej sprawie prowadzić może do zniweczenia celu i funkcji art. 31 k.p.a., czyniąc art. $31 \S 1$ pkt 2 k.p.a. $\mathrm{w}$ danej sprawie przepisem $\mathrm{w}$ istocie martwym ${ }^{33}$.

W sądownictwie administracyjnym przyjmuje się powszechnie, że w myśl art. $31 \S 1$ pkt 2 k.p.a. warunkiem skuteczności wniosku o dopuszczenie do udziału w postępowaniu jest pozostawanie tego postępowania w toku ${ }^{34}$. Odnotować należy, że NSA w wyroku z 18 września 2014 r. wskazał, iż dopuszczenie organizacji społecznej do udziału w postępowaniu administracyjnym dotyczy zarówno postępowania przed organem I, jak i II instancji. To, czy w momencie złożenia wniosku decyzja nie była ostateczna, pozostaje bez znaczenia o tyle, że po jej wydaniu organ I instancji nie ma możliwości procedowania. W przypadku złożenia wniosku o dopuszczenie do udziału w postępowaniu po zakończeniu postępowania pierwszoinstancyjnego organ I instancji powinien przede wszystkim ustalić, czy zostało wywołane postępowanie przed organem II instancji, gdyż tylko w takim wypadku organ będzie miał obowiązek dokonania merytorycznego badania wniosku. W razie zaś ustalenia, że postępowanie drugoinstancyjne nie toczy się, zachodzą podstawy do odmowy dopuszczenia organizacji społecznej do udziału w postępowaniu w sprawie wskutek wygaśnięcia uprawnienia określonego w art. $31 \S 1$ pkt 2 i 3 k.p.a. ${ }^{35} \mathrm{~W}$ sytuacji gdy

32 Z. Janowicz, op. cit., s. 285.

${ }^{33}$ Tak - wyroki NSA: z 3 II 2005 r., sygn. OSK 1076/04, LEX nr 165912; z 18 XI 2008 r., sygn. II OSK 1388/07; z 12 VI 2007 r., sygn. II GSK 20/07; z 25 X 2013 r., sygn. II OSK 1217/12, www.nsa.gov.pl (dostęp: 2 II 2017).

${ }^{34}$ Zob. wyroki NSA: z 3 II 2005 r., sygn. OSK 1076/04, LEX nr 165912; z 20 VI 2012 r., sygn. II OSK 525/11, LEX nr 1216745.

${ }^{35}$ Wyrok NSA z 18 IX 2014 r., sygn. II OSK 626/13, www.nsa.gov.pl (dostęp: 2 II 2017). 
organizacja społeczna wraz z wnioskiem o dopuszczenie do udziału w postępowaniu składa odwołanie od decyzji organu I instancji, organ dopiero po rozpatrzeniu wniosku organizacji społecznej o dopuszczenie do udziału w postępowaniu winien przekazać odwołanie organowi II instancji w celu jego zbadania pod kątem dopuszczalności wniesienia odwołania i zachowania terminu do jego wniesienia ${ }^{36}$. Nie zmienia to faktu, że konieczne jest zainicjowanie postępowania odwoławczego.

Zgodnie $\mathrm{z}$ drugim prezentowanym $\mathrm{w}$ orzecznictwie poglądem na temat momentu złożenia wniosku o dopuszczenie do udziału w postępowaniu organizacji „w sytuacji złożenia przez organizację społeczną wniosku o dopuszczenie do udziału w postępowaniu na podstawie art. $31 \S 1$ pkt 2 k.p.a. uprawnienie tej organizacji ${ }^{37}$ nie wygasa wskutek wydania decyzji kończącej to postępowanie nawet wówczas, gdy nabyła ona cechę formalnej ostateczności wobec niewniesienia odwołania. Wniosek ten nadal podlega merytorycznemu rozpatrzeniu"38. Pogląd ten został wyrażony na tle stanu faktycznego, w którym organizacja społeczna złożyła wniosek o dopuszczenie do udziału w postępowaniu i został on rozpatrzony przed wydaniem w sprawie decyzji kończącej postępowanie. Wyrok ten nie stoi w żaden sposób w sprzeczności ze stanowiskiem wyrażonym powyżej. Uwzględnia bowiem fakt, że złożenie żądania przez organizację w trybie art. $31 \S 1$ pkt 2 k.p.a. nie może nastąpić w każdym czasie. Do poglądu wyrażonego w powyżej wskazanym wyroku odniósł się także NSA w wyroku z 25 maja 2012 r. Zdaniem sądu "wykładnia art. 31 § 2 k.p.a. nie prowadzi do wniosku, że wydanie decyzji kończącej postępowanie administracyjne w danej instancji, nawet jeżeli nie jest ona ostateczna, stanowi samodzielną przesłankę negatywną uwzględnienia wniosku organizacji społecznej o dopuszczenie do udziału w sprawie dotyczącej innej osoby". W ocenie NSA "dopiero złożenie środka odwoławczego od decyzji nieostatecznej uruchamia administracyjny tok instancji, tzn. powoduje, że wszczęte zostaje postępowanie odwoławcze i tylko w takiej sytuacji możliwe jest rozpatrzenie wniosku organizacji społecznej, która nie brała udziału w postępowaniu. W konsekwencji wniesienie odwołania

${ }^{36}$ Wyrok NSA z 20 VI 2012 r., sygn. II OSK 525/11, www.nsa.gov.pl (dostęp: 2 II 2017).

${ }^{37}$ Do dopuszczenia jej do udziału w postępowaniu na prawach strony (art. $31 \S 3$ k.p.a.).

${ }^{38}$ Wyrok NSA z 12 VI 2007 r., sygn. II GSK 20/07, LEX nr 338613. 
przez organizację społeczna, która nie brała udziału w postępowaniu, stanowi podstawę stwierdzenia niedopuszczalności odwołania"39.

Podsumowując, odpowiedź na pytanie: w jaki sposób rozstrzygnąć żądanie organizacji społecznej o dopuszczenie do udziału w postępowaniu, które wniesione zostało po wydaniu decyzji organu I instancji, zależy od okoliczności danej sprawy. Sposób rozstrzygnięcia wiązać należy z tym, czy strona wniosła odwołanie. W sytuacji, gdy odwołanie nie zostało wniesione przez stronę, wobec związanego z zakończeniem postępowania wygaśnięcia uprawnienia organ I instancji winien wydać postanowienie o umorzeniu postępowania zainicjowanego wnioskiem organizacji społecznej ${ }^{40}$. Natomiast jeśli organizacja społeczna wraz z żądaniem o dopuszczenie do udziału w postępowaniu wniosła odwołanie, organ II instancji powinien uznać je za niedopuszczalne. $Z$ kolei wniesienie przez stronę odwołania powoduje, że postępowanie nie zostało zakończone, w związku z czym żądanie dopuszczenia do udziału w postępowaniu powinno być poddane merytorycznej ocenie ${ }^{41}$. Wówczas, jak przyjmuje NSA, rozpatrzenie wniosku o dopuszczenie do udziału w postępowaniu może przejść na organ II instancji ${ }^{42}$. Stanowisko to wydaje się jednak dyskusyjne wobec treści art. 132 § 1 k.p.a., gdyż dopuszczenie organizacji społecznej do udziału w postępowaniu przed organem I instancji prowadzić może do uwzględnienia odwołania wniesionego przez organizację społeczną.

Nie jest zatem możliwe pozytywne rozpatrzenie wniosku o dopuszczenie organizacji społecznej do udziału w postępowaniu po uprawomocnieniu się decyzji. Przyjęcie odmiennego rozwiązania prowadziłoby do naruszenia elementarnych zasad postępowania administracyjnego.

${ }^{39}$ Wyrok NSA z 12 VI 2007 r., sygn. II GSK 20/07.

${ }^{40}$ Por. wyroki NSA: z 3 II 2005 r., sygn. OSK 1076/05; z 19 XI 2014 r., sygn. II OSK 1066/13, www.nsa.gov.pl (dostęp: 2 II 2017).

${ }^{41}$ Wyrok NSA z 20 VI 2012 r., sygn. II OSK 625/11; zob. też: wyrok WSA w Warszawie z 6 VIII 2015 r., sygn. VI SA/Wa 204/15, www.nsa.gov.pl (dostęp: 3 II 2017).

${ }^{42}$ Wyrok NSA z 3 II 2005 r., sygn. OSK 1076/05, http://orzeczenia.nsa.gov.pl/doc/ 7237EF5A69 (dostęp: 2 II 2017). 